\title{
The Effect of Creatine Supplementation on the CPK Enzyme in Blood Serum and Some Physical Abilities for Wrestlers during the Competition Period.
}

\section{El efecto de la suplementación con creatina sobre la enzima CPK en el suero sanguíneo y algunas habilidades físicas de los luchadores durante el período de competencia.}

Received: October 26, 2020

Accepted: November 29, 2020

\author{
Written by: \\ Ehab S. Mohamed ${ }^{28,29}$ \\ Amr H. Tammam ${ }^{28,30}$
}

\begin{abstract}
Creatine phosphokinase $(\mathrm{CPK})$ is a binary enzyme that stimulates reverse phosphorylation to regenerate adenosine triphosphate. Creatine supplementation improves the Phosphagen system by increasing the amount of free creatine and phosphocreatine available to replenish adenosine triphosphate. The aims of this study are to investigate the effects of a creatine supplement on CPK enzyme, muscular endurance, power and agility performance compared to a placebo among wrestlers during the competition in a double-blind and randomized manner. Sixteen Wrestlers participated in the current study. They were divided into two groups; Experimental group $($ EXP) $(n=8)$ with creatine supplementation and a control group without creatine supplementation $(\mathrm{CON})(\mathrm{n}=8)$. They were tested before $(\mathrm{PRE})$ and after (POST) 8-week creatine supplementation period for CPK enzyme, muscular endurance [i.e. back-throw skill using the wrestling dummy], power [i.e. skill of the bridge], and agility [i.e. skill of the bridge in $10 \mathrm{sec}$.]. The results have shown statistically significant effects of the time (i.e. preto post-training) for all measured variables ( $\mathrm{p} \leq$ 0.05 ) of EXP group (whereas no significant effects $(p>0.05)$ of CON group. There were statistically significant differences $(p \leq 0.05)$ at the POST evaluation of EXP group in comparison with CON group for all study variables.
\end{abstract}

Keywords: Creatine phosphokinase; muscular endurance; power; agility.

\begin{abstract}
Resumen
La creatina fosfoquinasa $(\mathrm{CPK})$ es una enzima binaria que estimula la fosforilación inversa para regenerar el trifosfato de adenosina. La suplementación con creatina mejora el sistema de fosfágeno al aumentar la cantidad de creatina y fosfocreatina libres disponibles para reponer el trifosfato de adenosina. Los objetivos de este estudio son investigar los efectos de un suplemento de creatina sobre la enzima CPK, la resistencia muscular, la potencia y el rendimiento de la agilidad en comparación con un placebo entre los luchadores durante la competencia de una manera doble ciego y aleatoria. Dieciséis luchadores participaron en el estudio actual. Se dividieron en dos grupos; Grupo experimental $(\mathrm{EXP})(\mathrm{n}=8)$ con suplementación con creatina y un grupo control sin suplementación con creatina $(\mathrm{CON})(\mathrm{n}=8)$. Fueron evaluados antes (PRE) y después (POST) del período de suplementación de creatina de 8 semanas para la enzima CPK, resistencia muscular [es decir, habilidad de lanzar hacia atrás usando el muñeco de lucha], poder [es decir habilidad del puente], y agilidad [es decir habilidad del puente en $10 \mathrm{seg}$.]. Los resultados han mostrado efectos estadísticamente significativos del tiempo (es decir, antes y después del entrenamiento) para todas las variables medidas $(\mathrm{p} \leq 0.05)$ del grupo EXP (mientras que no hubo efectos significativos $(\mathrm{p}>0.05)$ del grupo CON. Hubo diferencias estadísticamente significativas $(\mathrm{p} \leq 0.05)$ en la evaluación POST del grupo EXP en comparación con el grupo $\mathrm{CON}$ para todas las variables del estudio.
\end{abstract}

Palabras claves: Creatina fosfoquinasa; endurecimiento muscular; poder; agilidad.

\footnotetext{
${ }^{28}$ Department of General Courses, Faculty of Education and Arts, Northern Border University, Saudi Arabia.

${ }^{29}$ Department of Individual Sports, Faculty of Physical Education, Tanta University, Egypt.

${ }^{30}$ Department of Training and Sports Movement Sciences, Faculty of Physical Education, Tanta University, Egypt.
} 


\section{Introduction}

Performance-enhancing aids for athletes are classified into different categories such as mechanical aids (e.g. the use of lighter sports equipment, bicycle equipment designed to reduce air resistance), drugs (e.g. caffeine intake, male hormones, erythropoietin), physiological aids (e.g. sodium bicarbonate, sodium citrate, blood transfusion), and nutrients (e.g. carbohydrate supply, vitamins, amino acid subchains, creatine). (Sabry, 2006)

The intake of some supplements (creatine, phosphorus, and amino acids, for example) according to the athlete's need is a codified process that has positive effect on athletic reconstruction and strength recovery. (Shehata, 2000)

Creatine has become one of the most common ingredients in dietary supplements, especially sports nutrition products. (Salama, 1999) It is an organic nitrogen compound, which is often obtained from external sources such as meat, fish and other animal products. There is also a small amount in some plants. Creatine is found in a large amount in meat and fish, where each kilogram contains 5 grams of creatine. It can also be replaced by internal sources, which are mainly synthesized in the liver, pancreas and kidneys from some of the essential amino acids, glycine, Arginine and Methionine (Abdel Fattah, 2003). Skeletal muscles are the first storage of creatine, containing $95 \%$, while the heart muscle, brain, kidneys and testes contain $5 \%$.

The process of creatine formation takes place in three steps in the kidneys, liver and pancreas as follows: (1) In the first step, the amidine group moves amidin from arginine to the amino acid to form the compound of guanido. (2) In the second step, the group of Methionine moves from the amino acid to glyco ciamide to form creatine. (3) The third step removes a water molecule of creatine to form creatinine, which is excreted in the urine (Greenhaff, 1998).

The individual gets his daily creatine needs in the range of 1-2 grams through food sources. This amount can be enough to maintain the natural level of creatine. Creatine levels are low in the muscles of some other people such as vegetarians and low-food due to low food sources of creatine in their daily diet. The body needs about 2 grams per day of creatine and gets half the amount directly through the group of amino acids with food. In order to benefit from the functions of creatine in the field of sports, muscles are loaded with doses of creatine that are more than required. However, this process is always temporary and creatine levels return to what they were during a certain period of time (Abdel Fattah, 2003).

Creatine monohydrate is one of the most common sports supplements which is used to achieve high levels of phosphate needed to generate energy during exercise. (Brudnak, 2004) Creatine also plays a key role in the energy metabolism of skeletal muscles as a partial donor of the two phosphate (P) needed to rephosphorylation of adenosine phosphate (ADP) in order to maintain the body's supply of triphosphate adenosine phosphate (ATP) during the rapid increase in energy required by the breakdown of phosphate creatine PC. This reaction in the presence of the creatine enzyme phospho-kinase CPK is a reverse one. It is a twoway reaction where it goes to the right when ATP transition to the places of benefit, while to the left when moving ADP to the places of power generation mitochondria according to the following reaction:

$\mathrm{PCR}+\mathrm{ADP}+\mathrm{H}+$

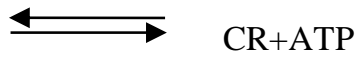

(Refaat, et al. 1999)

Creatine phosphokinase (CPK) is a binary enzyme that stimulates the reverse phosphorylation of the phosphate adenosine through creatine phosphate to form adenosine triphosphate (Haslett, 2004). The skeletal muscle is the richest source of the CPK enzyme (99\%), while the heart muscle and brain have a lower percentage. There is CPK enzyme in three similar images which are called analogues enzymes, namely:

CPK. BB1. Or (CPK1) is found in the brain or smooth muscle.

CPK. MB1 or CPK2)) is found in the heart muscle.

(CPK3) CPK. MM1 is found in skeletal muscle.

In normal conditions, this enzyme is present in small amounts in the blood. However, with increased performance requirements, the activity and synthesis of muscle cells are disrupted, resulting in an increased level of activity (CPK) in the blood (Shuaib, 2015). Creatine intake has become popular among individuals participating in various sports. In biochemical terms, creatine improves creatine and phosphocreatine 
concentrations, allowing increased sources of creatine for muscles. In terms of thermodynamics, creatine interferes with the creatine-creatine-phosphocreatine cycle. (Benzi, 2002). The researchers emphasize that creatine is not included in the list of doping internationally banned by the International Olympic Committee (IOC) and authorized to take it, as confirmed (Refaat,1999). Creatine intake leads to improve short-term performance with high intensity and frequency (Howard, 2006).

Recently, players are increasingly taking these supplements. Creatine is the biggest contributor to athletes because it is not a banned substance and has a positive effect as a key source of energy. It helps athletes increase speed and ability to exert more effort during sports activities. Wrestling is one of the oldest martial arts practices dating back to $708 \mathrm{BC}$ at the ancient Greek Olympic Games (Barroso et al., 2011) It is known that there are 2 internationally recognized forms of competitive wrestling. One of the is Freestyle and the other is Greco-Roman (Özer,2019) Wrestlers have to be adopted to repetitive bouts of high-intensity actions to be successful. Maximal strength, muscular endurance, maximal aerobic power, and anaerobic capabilities, power are needed to have victory for wrestlers in wrestling competition (Chaabene et al., 2017).

The human body has to be in great balance physical, physiological, biometric (Çakmakçi et al., 2018; Tatlici et al., 2018), Wrestling is a highly intensive sport, which requires a great effort of the player to bear the burdens of the game. It became like other sports in which players accept to food aids, including creatine, and the consumption of varying doses which are not regulated. Every player uses creatine in a personal way or according to what he hears from players taking creatine.

The researchers notice that taking that component is done in a random and irregular method. This certainly affects many vital functions of the body and various enzymes. This is what the researchers observed through their readings and personal interviews with many specialists in the field of medicine and analysis, who also confirmed that one of the important enzymes in the body is the CPK enzyme. Multiple images in the body in ordinary muscles call this enzyme (MM) while in the heart it is called (MB). Moreover, this enzyme is found in the brain with a certain percentage. It is called (BB). It plays an important role in the production of energy in muscle.
Several studies have identified the effect of creatine intake on athletes, including the study which shows that taking creatine increases the content of total creatine while not increasing the phosphocreatine. It also shows that taking creatine leads to improving the level of performance during training (Refaat,1999).

Shows players loading of standard doses of creatine namely, 20 grams per day 4 times- each time 5 grams- for 4-5 days in the first week and then taking 5 grams before the training unit for the rest of the program lasted for eight weeks. The study shows improved body mass index (BMI). The players were not totally affected by the regulated doses of creatine (Sabry, 2000).

Several studies have shown positive results for cintake in some of physical abilities, study of shown improves overall and repeated short duration sprint cycling performance after using Creatine-electrolyte supplementation in a double-blind randomized control study (Crisafulli, 2018).

Similarly, in his study used Creatine-electrolyte supplementation in a double-blind randomized control study. Results show benefits in bench press and back squat maximal strength as well as multiple repetition tests to fatigue during the bench press exercise (Hummer et al., 2019).

On the other hand, the study of has not shown improvement in anaerobic sprint capacity while whole body creatine retention and muscle free creatine content were increased (Oliver et al., 2014).

Study used creatine supplementation combined with resistance training on urinary formaldehyde. The results show that resistance training lowers the increase of urinary formaldehyde excretion induced by creatine supplementation for male wrestlers (Nasseri, 2016). The interest in training helps in developing the strength of the player (Yüksel et al., 2019), (Yonca et al, 2017) and physiological aids also help to improve the player's performance

According to the researchers, the problem of the research lies in the absence of studies that confirm the proper ratios of taking creatine by athletes of wrestling sport, which is characterized by high loads and intensity during training as well as during the game where pulse limits reach the maximum limits. A further reason for conducting the current research is the lack of enough studies to determine the effect of creatine intake on the enzyme CPK and some physical 


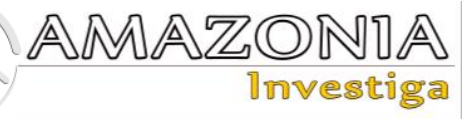

abilities in wrestlers during the competition period. Therefore, the aim of the research is to identify the effect of creatine intake on the CPK enzyme and some physical abilities (muscular endurance, ability, agility) in wrestlers during the competition.

\section{Research Aims:}

The research aims to identify the effect of creatine intake on CPK enzyme and some physical abilities (muscular endurance, ability, fitness) among wrestlers during the competition period.

\section{Research Hypotheses:}

Creatine intake leads to increase the CPK enzyme level and improve some physical abilities (muscular endurance, ability, and agility) among wrestlers during the competition period.

\section{Methods Subjects}

Sixteen Wrestlers from Shooting Club volunteered to participate in the current study. They were distributed in a balanced manner according to their pre-values of study variables into two groups; experimental group (EXP) $(\mathrm{n}=8)$ with creatine supplementation and a control group without creatine supplementation $(\mathrm{CON})(\mathrm{n}=8)$. The inclusion criteria for the participants were healthy, free from any injuries, and no use of any ergogenic supplements. All participants were fully informed about the study and possible risks before giving their written consent to participate. The research project was conducted in accordance with the Declaration of Helsinki for Human Research. The study was approved by the Deanship of Scientific Research, Northern Border University, Arar, K.S.A. The subjects' characteristics are presented in (Table 1).

Table 1.

Subjects' Pre-experimental Characteristics.

\begin{tabular}{|c|c|c|c|c|c|c|c|c|}
\hline \multirow[t]{2}{*}{ Variables } & \multicolumn{2}{|l|}{$\begin{array}{l}\mathrm{CON} \\
(\mathrm{n}=8)\end{array}$} & \multicolumn{2}{|l|}{$\begin{array}{l}\text { EXP } \\
(n=8)\end{array}$} & \multirow[t]{2}{*}{$(\boldsymbol{P})$} & \multicolumn{3}{|c|}{$\begin{array}{l}\text { Total } \\
(n=16)\end{array}$} \\
\hline & Mean & \pm SD & Mean & \pm SD & & Mean & \pm SD & Skew. \\
\hline Age (y) & 22.88 & 1.13 & 22.63 & 1.19 & 0.672 & 22.75 & 1.13 & -0.40 \\
\hline Weight (kg) & 77.63 & 1.69 & 78 & 2.20 & 0.708 & 77.81 & 1.91 & -0.49 \\
\hline Height $(\mathrm{cm})$ & 178.38 & 1.60 & 179.38 & 4.21 & 0.540 & 178.88 & 3.12 & 2.40 \\
\hline CPK (U/L) & 217.88 & 68.65 & 223.63 & 72.39 & 0.873 & 22.75 & 68.13 & -0.20 \\
\hline Muscular Endurance & 10.38 & 1.30 & 10 & 1.31 & 0.575 & 10.19 & 1.28 & -0.40 \\
\hline $\begin{array}{l}\text { (no.) } \\
\text { Power (Sec) }\end{array}$ & 8.38 & 1.19 & 8.50 & 1.07 & 0.828 & 1.69 & 0.60 & 0.01 \\
\hline $\begin{array}{l}\text { Power (Sec) } \\
\text { Agility (no.) }\end{array}$ & 1.75 & 0.71 & 1.63 & 0.52 & 0.693 & 8.44 & 1.09 & 0.21 \\
\hline
\end{tabular}

$\mathrm{CON}=$ control group without Creatine intake; $\mathrm{EXP}=$ Experimental group with creatine intake; CPK; creatine phosphokinase; no significant differences for pre-experimental characteristics between groups.

\section{Experimental Design}

The study started in October 2018 during the competition period and was conducted in a double-blind and randomized manner. The independent variable was creatine supplementation. Dependent variables included CPK, muscular endurance, power, and agility. All variables were tested before (PRE) and after (POST) 8-week creatine supplementation period. One week before the start of the experiment, all subjects reported to the Shooting Club indoor hall two times in non-consecutive days. On the 1 st visit; all subjects were provided with an information sheet setting out details of the experiment. Written informed consent were completed and signed. They changed into sports clothes (running shoes, shorts, and t-shirt). Body weight and height were recorded by using a balance weighing scales and portable stadiometer respectively.

Two days after the 1 st visit, blood samples were withdrawn by the physician. All subjects were tested for agility first, then power, and finally muscular endurance as a PRE- evaluation. Before the test, subjects performed a warm-up which included $5 \mathrm{~min}$ of light running and $5 \mathrm{~min}$ dynamic stretching exercises. All testing sessions for two groups used the same test order, equipment, warm-up, and time of the tests (between 5:00 and 8:00 PM). The POSTevaluation was performed for each group after 8 -week creatine supplementation. All testing sessions were supervised by the same authors and one physician. 


\section{CPK Measurements}

Following a minimum of $15 \mathrm{~min}$ of rest in a supine position, a $5 \mathrm{~mL}$ resting blood sample was collected from the cephalic vein in the forearm. The blood samples were kept in tubes containing a substance heparin to prevent blood clotting and quoted in ice for the analysis on the same day. The blood was analyzed for CPK using MindrayBA-88A a Semi-Auto Chemistry Analyzer (Mindray, Shenzhen, China).

\section{Muscular Endurance}

Test of the back-throw skill using the wrestling dummy for 1 min used to determine the muscular endurance. The number of times of the correct performance was calculated, which is going down and holding the wrestling dummy and then turn on the front after reaching the ground and then stand and repeat for a minute.

\section{Power}

Test of performing the skill of the bridge for three times in less time used to determine the power. The subject stands in the middle of the rug and performs three times the skill of the bridge quickly. Correct performance is based on the feet and the forehead and hands and then get rid of the bridge and stand. The time of performance was calculated.

\section{Agility}

Test of the count of the performance of the skill of the bridge in $10 \mathrm{sec}$. used to determine the agility. The subject stands in the middle of the rug and performs the skill of the bridge quickly. Correct performance is based on the feet and the forehead and hands and then get rid of the bridge and stand, and the count of the performance was calculated.

\section{Supplementation Protocol}

The protocol consists of 8 -weeks. Participants were randomly assigned to take the creatine supplements, in a double -blind and randomized manner. Thirty min prior the training session with supervised by authors, all subjects take a drink. Each drink was 250 mil juice containing 520 grams of unflavored creatine monohydrate powder (CMP) (MYPROTEIN, Lindon, UT, USA) or a placebo drink (P) was 250 mil juice without creatine monohydrate powder. All details about the amount of creatine supplementation during the 8-weeks of supplementation period were illustrated in (table 2).

Table 2.

The Supplementation Protocol.

\begin{tabular}{|c|c|c|c|c|}
\hline weeks & $\begin{array}{l}\text { Ingestion days/ } \\
\text { week }\end{array}$ & $\begin{array}{l}\text { Ingestion amount/ day } \\
\text { (g.) }\end{array}$ & $\begin{array}{l}\text { Total ingestion/ week } \\
\text { (g.) }\end{array}$ & $\begin{array}{l}\text { Total } \\
\text { (g.) }\end{array}$ \\
\hline 1 & 4 & 20 & 80 & \multirow{8}{*}{245} \\
\hline 2 & 4 & 5 & 20 & \\
\hline 3 & 4 & 5 & 20 & \\
\hline 4 & 5 & 5 & 25 & \\
\hline 5 & 5 & 5 & 25 & \\
\hline 6 & 5 & 5 & 25 & \\
\hline 7 & 5 & 5 & 25 & \\
\hline 8 & 5 & 5 & 25 & \\
\hline
\end{tabular}

\section{Statistical Analysis}

Data are presented as mean and standard deviations $( \pm \mathrm{SD})$. The statistical calculations were performed using STATISTICA software version 10 (Stat Soft, Tulsa, OK, USA). All variables presented normal distribution and homoscedasticity. Independent t-test was used to test for significant differences between EXP and CON groups, a paired sample t-test was used to test for significant differences between PRE, and POST variables for each group.

\section{Results}

There were no differences between the two groups in the PRE- test for all study variables $(p>0.05)$. All subjects of EXP group completed the 8-week creatine intake. The study has shown statistically significant effects of the time (i.e. pre- to post-training) for all measured variables $(p \leq 0.05)$ of EXP group (whereas no significant effects $(p>0.05)$ of CON group. There were statistically significant differences $(p \leq 0.05)$ at the POST evaluation of EXP group in comparison with CON group for all study variables (Table 3 ). 
Table 3.

Pre- and Post-testing Data of Each Variable for Each Group.

\begin{tabular}{|c|c|c|c|c|c|c|c|}
\hline \multirow{2}{*}{ Variable } & \multirow{2}{*}{ Group } & \multicolumn{2}{|l|}{ PRE } & \multicolumn{2}{|l|}{ POST } & \multirow{2}{*}{ (p1) } & \multirow{2}{*}{$-(p 2)$} \\
\hline & & Mean & \pm SD & Mean & \pm SD & & \\
\hline \multirow{2}{*}{ CPK (U/L) } & $\mathrm{CON}$ & 217.88 & 68.65 & 219.38 & 67.85 & 0.606 & \multirow{2}{*}{0.000} \\
\hline & EXP & 223.63 & 72.39 & $607^{* \#}$ & 155.88 & 0.000 & \\
\hline \multirow{2}{*}{$\begin{array}{l}\text { Muscular } \\
\text { Endurance }\end{array}$} & $\mathrm{CON}$ & 10.38 & 1.30 & 10.75 & 1.39 & 0.197 & \multirow{2}{*}{0.002} \\
\hline & EXP & 10 & 1.31 & $12.38^{* \#}$ & 0.74 & 0.000 & \\
\hline \multirow{2}{*}{ Power (Sec) } & $\mathrm{CON}$ & 8.38 & 1.19 & 8.50 & 1.51 & 0.598 & \multirow{2}{*}{0.003} \\
\hline & EXP & 8.50 & 1.07 & $10.13^{* \#}$ & 0.64 & 0.002 & \\
\hline \multirow{2}{*}{ Agility (no.) } & $\mathrm{CON}$ & 1.75 & 0.71 & 2 & 0.76 & 0.170 & \multirow{2}{*}{0.036} \\
\hline & EXP & 1.63 & 0.52 & $3.38^{* \#}$ & 1.19 & 0.004 & \\
\hline
\end{tabular}

Values were expressed by mean $\pm \mathrm{SD}, \mathrm{CON}=$ control group without Creatine intake $(n=8)$; $\mathrm{EXP}=$ Experimental group with creatine intake, $(\mathrm{n}=8) ; \quad \mathrm{CPK}=$ creatine phosphokinase; *= statistically significant differences between PRE and POST; \#= statistically significant differences between CON and EXP in POST measurement; $\mathrm{P} 1=$ probability value for statistically significant differences between PRE and POST; P2= probability value for statistically significant differences between CON and EXP in POST measurement.

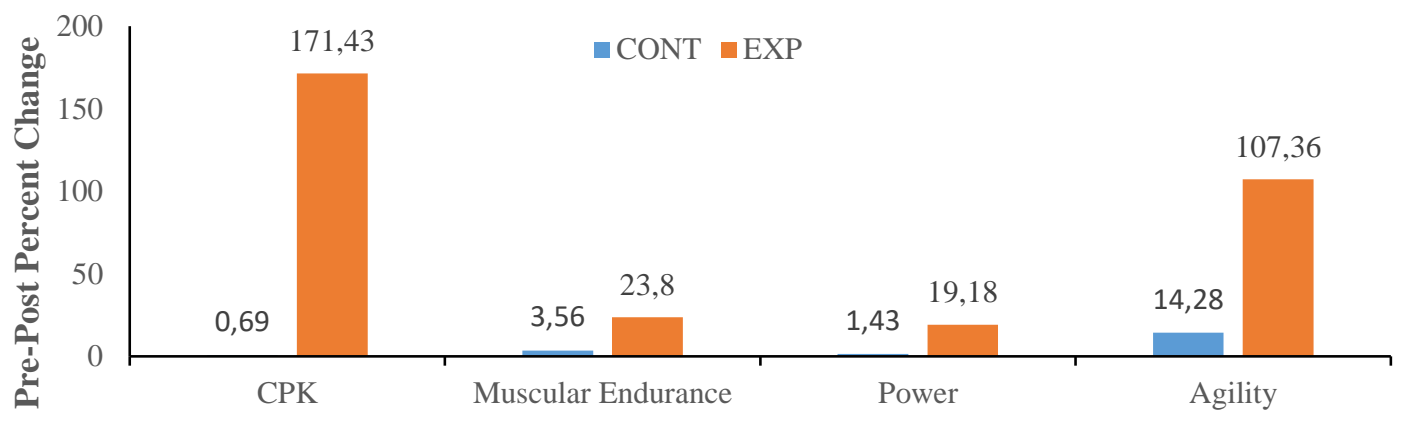

Fig 1. Rate of changes in study variables for all groups, the EXP group shown a higher percentage increase in all variables than $\mathrm{CON}$ group, $\mathrm{CPK}=$ creatine phosphokinase; $\mathrm{CON}=$ control group without Creatine intake; $\mathrm{EXP}=$ Experimental group with creatine intake.

The study has shown statistically significant differences favor EXP group $(\mathrm{p} \leq 0.05)$ at the POST evaluation in CPK, muscular endurance, power, and agility $(171.43 \%, 23.8 \%, 19.18 \%$, and $107.36 \%$; respectively) in comparison with the CON group $(0.69 \%, 3.56 \%, 19.18$, and 14.28\%; respectively). (Table 2) (Fig. 1).

\section{Discussion}

According to the objective of the present study and based on the results of the statistical analysis of the two groups, the experimental one in which players dealt with creatine at specific doses and the control one that did not take creatine. After eight weeks the CPK enzyme and some physical variables (muscle endurance, ability, fitness) were measured, it is clear from Table (3) that there are statistically significant differences between the experimental and control groups in the telemetry increase in CPK enzyme, in favor of the telemetry of the experimental group.

Figure (1) shows that the percentage changes in telemetry compared to the pre-measurement in the concentration of enzyme. The control group CPK was $(0.69 \%)$ and the experimental group was $(171.43 \%)$. The researchers attribute this to the effect of creatine supply, which makes metabolic processes run normally unchanged, disrupting the desired and proper metabolic pathways. It shows that creatine supply ratios at those regulated doses gives a good indication of the safety of the successful application of the experiment which is consistent that most athletes before the competition try to increase creatine phosphate by loading this compound in standard doses It is also similar to the results of the (Rafiq, 2016). It also shows an improvement in the level 
of the enzyme CPK and the level of performance of 200 meters running.

The current study also shows that the enzyme levels have reached high limits for the experimental group than the control one in the telemetry. This is shown in Table (3). Excessive intake of supplements, especially creatine should be dealt with very cautiously after this very high increase as revealed in the current study so as not to affect the work of the various body systems. Taking creatine with training during the competition period has the greatest effect in raising the levels of this enzyme to those high limits.

Some studies have shown that CPK rise is due to higher training loads. This is confirmed by (Mohammed, 2016). The results of the study also confirmed the validity of the researchers' assumption of the effect of taking dietary supplement, creatine on CPK enzyme. This is confirmed by the recommendation of the study by (Shuaib, 2015) on the use of biochemical indicators, especially enzymes when giving supplements. It is a real indicator of the activity of most supplements in the muscles of the body. The increase in CPK enzyme (Figure 1) is consistent with the results of the study by (Rafiq, 2016) which shows that whenever the athlete ingested sufficient quantities of this compound, the storage of skeletal muscle increases from the PC and thus its ability to maintain a high concentration of ATP also increase. Its ability to maintain a high concentration of ATP will be increased by reconstituting it from the PC association with ADP and then maintaining muscle contraction during high-intensity physical effort.

Table (3) shows that there are statistically significant differences between the experimental and control groups in favor of the experimental group in the telemetry of some physical abilities (muscular endurance, ability, fitness) of the study sample. This is also shown in Figure (1) in which the ratios show tha change in the control group in the variables (muscular endurance, ability, fitness) (3.56, 1.43, 14.28), respectively. Similarly, the change rates for the experimental group of these physical variables $(23.8,19.18$, 107.36), respectively, indicates the supply of creatine in a standardized way has resulted in a remarkable improvement in the physical abilities of the sample under study from the experimental group.

There is a relationship between increased concentration of enzyme CPK, high physical capacity to increase this stock enzyme in the body and the rise of increasing amounts of compound creatine phosphate muscle. This gives a good indication of muscular Ohz which was confirmed by (Rafiq, 2016) (Murphy, et al. 2005) which states that the high level of concentration of the enzyme CPK is an indicator of good muscular action as well as the increase of creatine phosphate compound in muscle.

Similarly, (Shuaib, 2015) citing James Collier, 2004, states that the more creatine stores in the body and muscles, especially in skeletal muscles, the greater the ability to reconstitute ATP. This helps create energy reserves that would contribute to the higher physical abilities of the players. This is also confirmed by (Brudnak, 2004) shows that creatine intake is one of the most common sports supplements to achieve the high levels of phosphate needed to generate energy during exercise.

Wrestling sport is characterized by high loads. The game time is short, especially in the rounds. Therefore, the game system is dominated by the lactic system and the creatine phosphate PC system. The body always needs a supply of PC by the reverse reaction from the conversion of ADP to ATP, therefore the supply of standard creatine doses used by researchers in the current study has contributed, from their point of view, to the availability of ATP which helps raise the physical abilities of the players, as demonstrated by the current study.

The researchers also believe that the percentages prescribed in the supply of creatine were ratios and influential in increasing the level of enzyme CPK and high level of physical abilities of the sample under study. Based on the previous studies in this area, creatine was taken by about 20 grams per day for a week, 5 grams for two weeks, 4 times a week and 5 grams for another five weeks at 5 times a week. This is confirmed by (Rawson, et al. 2001) (Sabry, 2006). These doses are the appropriate and regulated one when taking creatine doses. Therefore, The orientation towards achieving the goal determines the identity of the player (Kondakov, 2018, Ivanova, Korostelev, 2019).

the research hypothesis that creatine intake leads to elevated CPK enzyme level and improves some physical abilities (muscular endurance, ability, and agility) in wrestlers during the competition period has been validated. 


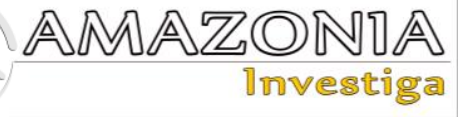

Conclusions

Regulated creatine supply significantly increases CPK enzyme level and improves some physical abilities (muscular endurance, ability, and agility).

\section{Recommendations}

Based on the findings of the present study and the conclusions drawn from the presentation and discussion of the results, the researchers recommend the following:

1. When supplied with creatine, the recommended dose is 20 grams per day 4 times, each time 5 grams, for 4-5 days in the first week.

2. It is recommended that after the loading period, creatine should be provided by 5 grams only before the training unit per day, after the load period in the first week. The duration of eight weeks period is appropriate for the continuation of the supply of creatine.

3. Creatine doses should be taken with caution as the limits of the rate of change, according to the doses in the present study, are codified and scientific. Care should be taken when skipping these doses so as not to adversely affect CPK enzyme activity.

4. Permanent laboratory examination of players to identify should be made to identify changes in the activity of the CPK enzyme in the blood serum for players who are constantly supplied with creatine to avoid the risks they may be exposed to.

5. Further studies should be conducted to identify the effect of creatine supply on various body functions throughout the training season for wrestling players or other sports players.

\section{References}

Abdel Fattah, A.A. (2003). Physiology of Training and Sport. Cairo: Dar Al Fikr.

Barroso, B. G., da Silva, J. M., Garcia, A. D., Ramos, N. C. D. O., Martinelli, M. O., Resende, V. R., \& Santili, C. (2011). Musculoskeletal injuries in wrestling athletes. Acta Ortop Bras, 19, 98-101.

Benzi, G. (2002). Is there a relation for the use of Creatine either as nutritional supplementation or as drug administration in human participants in sports? Italy: University of Pavia.

Brudnak, M. A. (2004). Are the benefits worth the risk? Toxicology Letters. 15(1), 123-130.
Çakmakçi, E., Tatlici, A., \& Yirmibeş, B. (2018). Comparison of Some Performance Parameters of Physically Active Mentally Retarded and Inactive Mentally Retarded Individuals. European Journal of Physical Education and Sport Science. 4 (12), 49-57

Chaabene, H., Negra, Y., Bouguezzi, R., Mkaouer, B., Franchini, E., Julio, U., \& Hachana, Y. (2017). Physical and physiological attributes of wrestlers: an update. The Journal of Strength \& Conditioning Research, 31(5), 1411-1442.

Crisafulli, D. L., Buddhadev, H. H., Brilla, L. R., Chalmers, G. R., Suprak, D. N., \& San Juan, J. G. (2018). Creatine-electrolyte supplementation improves repeated sprint cycling performance: A double blind randomized control study. Journal of the International Society of Sports Nutrition, 15(1), 21.

Rawson, E. S., Gunn, B. \& Clarkson, P.M (2001). The Effects of Creatine Supplementation on Exercise-Induced Muscle Damage, Journal of Strength and Conditioning Research, 15(2), 178-184

Greenhaff, P. L. (1998). The nutritional biochemistry of creatine. University Medical School. United Kingdom: Queen is UH

Haslett, C. (2004). Principles and Practice of Medicine. 19 TH Ed. New York: Churchill Livingstone.

Howard, T. M., Butcher, J. D. (2006). The little black book of sports medicine. Sudbury, Massachusetts: Jones and Bartlett Publishers.

Hummer, E., Suprak, D. N., Buddhadev, H. H., Brilla, L., \& San Juan, J. G. (2019). Creatine electrolyte supplement improves anaerobic power and strength: a randomized double-blind control study. Journal of the International Society of Sports Nutrition, 16(1), 24.

Kondakov, V. L., Kopeikina, E.N., Nikulina, D.E., Voloshina, L.N., Balysheva, N.V. (2018). The orientation on the student's identity and its influence on size and nature of physical activity. Revista Amazonia Investiga, $7(13)$. 58-64. https://amazoniainvestiga.info/index.php/amazo nia/article/view/494

Mohammed, S. Y. (2016). The Effect of Proposed Exercises for Developing Special Speed in Some Physical and Functional Capabilities and Enzyme (CPK) in Blood for Young Players Handball. Journal of Physical Education Sciences. 9(6).

Murphy, A.J., Watsford1. M.L., Coutts1, A.J. Richards, D.A.B. (2005). Effects of creatine supplementation on aerobic power and cardiovascular structure and function, Journal of Science and Medicine in Sport, 8 (3), 305-313 
Nasseri, A., \& Jafari, A. (2016). Effects of creatine supplementation along with resistance training on urinary formaldehyde and serum enzymes in wrestlers. The Journal of sports medicine and physical fitness, 56(4), 458-464

Ivanova, N.L., Korostelev, A.A (2019). The impact of competitive approach on students' motivation in sport. Revista Amazonia Investiga. $8(18)$. 483-490. https://amazoniainvestiga.info/index.php/amazo nia/article/view/362

Oliver, J. M., Jagim, A. R., Pischel, I., Jäger, R., Purpura, M., Sanchez, A., Kelly, K. (2014). Effects of short-term ingestion of Russian Tarragon prior to creatine monohydrate supplementation on whole body and muscle creatine retention and anaerobic sprint capacity: a preliminary investigation. Journal of the International Society of Sports Nutrition, 11(1), 6.

Özer, Ö. (2019). Investigation of the Effect of Acute Muscular Fatigue on Static and Dynamic Balance Performances in Elite Wrestlers. Journal of Education and Learning, 8(5), 179-184.

Rafiq, S. H. (2016). Effect of using creatine phosphate loading in the development of CPK enzyme and achievement of $200 \mathrm{~m}$ running", Faculty of Education and Humanities. Department of Basic Physical Education. Journal of Physical Education Sciences. 9(1), 219-235.

Refaat, O. H., Abdel Fattah, A. A., Shehata, A. H. (1999). Creatine supply between reality and caveats - a reference study. International Scientific Conference (physical education and sports between theory and practice), 2. Cairo.
Sabry, E. (2006). Effect of Creatine Supply on Some Physiological Functions of Kidneys and Body Mass Index in Gladiators. Higher Institute of Public Health. 36(3), 829-842.

Sabry, E. M. (2000). Effect of a training program to reduce the concentration of lactic acid in the blood on some physiological variables and the effectiveness of the skill performance of the wrestlers. (Unpublished Doctoral Dissertation). Tanta University, Faculty of Physical Education, Egipto.

Salama, B. I. (1999). The vital representation of energy in the sports field. Cairo: Dar Al Fikr.

Shehata, A.H. (2000). Creatine Supply and Dreams of Short-distance Runners. Regional Development Center Bulletin Athletics. 2.

Shuaib, J. M. (2015). Effect of Regular Doses of Creatine as a Function of CPK Enzyme in Developing Some Special Physical Capabilities of Romanian Advanced Wrestlers. Karbala Journal of Physical Education Sciences, 2 (3), 261-279

Tatlici, A., Çakmakçi, E., Yilmaz, S., \& Arslan, F. (2018). Comparison of visual reaction values of elite deaf wrestlers and elite normally hearing wrestlers. Journal of Turkish Sport and Exercise, 20(2), 63-33.

Yonca, S. S., Engin, Ç. B., Serdar, Y. A., Mustafa, K., Yüksel, S. (2017). The Effects of Unit Exercises on the Hand Grip Strength of Arm Wrestlers. Journal of Education and Training Studies, 5(6), 196-201.

Yüksel, O., Gündüz, B, Kayhan, M. (2019). Effect of CrossFit Training on Jump and Strength. Journal of Education and Training Studies, 7(1), 121-124. 